\title{
From Mobile Language Learning to Gamification: an Overlook of Research Results with Business Management Students over a Five-Year Period
}

\author{
ANDRÁs KÉTYI \\ Budapest Business School
}

Received: 21 December 2015 / Accepted: 18 April 2016

ISSN: $1697-7467$

\begin{abstract}
After a successful pilot project using busuu, we tested the chosen language learning application's effectiveness with learners of four languages (German, English, Spanish, Italian) ( $\mathrm{n}=94)$ using pre and post language tests. According to the language test results, the experimental group increased their performance $(+2.2 \%)$ while the control group's performance decreased $(-3.1 \%)$ and the difference in post-measurement was statistically significant ( $\mathrm{p}=.013$ ). Shortly after this, we tested Lifeline, a text-based interactive sci-fi story, which combines reading with a game. The students' feedbacks show that they found the app very motivating and exciting. Further research will focus on the effectiveness of Lifeline in language learning.
\end{abstract}

Keywords: German (language), second language, foreign language, computer application, mobile educational services, educational game.

Del aprendizaje de lenguas usando dispositivos móviles a la gamificación: resumen de los resultados de 5 años de investigación con estudiantes de Dirección de Empresas

RESUMEN: Tras un exitoso proyecto piloto usando busuu, se ha evaluado la efectividad de esta aplicación para el aprendizaje de idiomas con estudiantes de 4 lenguas (alemán, inglés, español e italiano) $(\mathrm{n}=94)$ usando pruebas previas y posteriores de sus conocimientos al respecto. Los resultados de estas pruebas muestran que el grupo experimental aumentó su rendimiento $(+2,2 \%)$, mientras que el propio del grupo de control decreció $(-3,1 \%)$ y su diferencia tras la segunda prueba de evaluación es estadísticamente significativa $(\mathrm{p}=0,013)$. Inmediatamente después, se hizo un nuevo experimento con Lifeline, una historia de ciencia ficción interactiva basada en la escritura de textos, que combina lectura y juego. Los estudiantes, a la vista de sus comentarios de evaluación de la experiencia, encontraron esta aplicación para móviles muy motivadora y excitante, por lo que futuras investigaciones se centrarán en la efectividad de Lifeline en el aprendizaje de lenguas.

Palabras clave: alemán (lengua), segunda lengua, lengua extranjera, programa informático, servicios educativos móviles, juego educativo.

\section{INTRODUCTION}

The term mobile assisted language learning (MALL) was created long before smartphones were available thanks to various mobile devices such as personal digital assistants (PDAs), 
palmtops, mp3 players, iPods and mobile phones. The objective of these mobile devices was primarily not pedagogical, but they were very soon implemented in teaching practice and second language acquisition (Waycott and Kukulska-Hulme, 2003; Kukulska-Hulme and Shield, 2008; Stockwell, 2008; Abdous, Camarena and Facer, 2009; Kukulska-Hulme, 2009; Stockwell, 2010; Goodwin-Jones, 2011; Palalas and Olenewa, 2012), sometimes, however, MALL activities rather mirrored early CALL activities (Kukulska-Hulme and Shield, 2008). The real breakthrough in functionality was the appearance of iPhone in 2007. iPhone, the first smartphone, was virtually a real palm-sized computer capable of performing every common computer task, but with an enhanced portability. In the last few years, due to the popularity and penetration of mobile devices, numerous empirical researches were conducted in the field of MALL predominantly with positive conclusions (Vesselinov and Grego, 2012; Viberg and Grönlund, 2012; Lee et al., 2014). Findings of a review of empirical MALL research studies published between 2007 and 2012, concerning the use and effectiveness of MALL in second and foreign language education, found that the majority of the researches were descriptive and only one paper analyzed quantitative/qualitative data in a systematic manner (Viberg and Grönlund, 2012). Thanks to the ongoing penetration of mobile devices, empirical MALL studies collecting quantitative and qualitative data has increasingly emerged (Vesselinov and Grego, 2012; Lee et al., 2014).

In a representative research using the language learning app Duolingo over eight weeks $(n=556)$ the experimental group significantly increased their performance $(p<0.01)$ and the main factor for higher effectiveness was the motivation of the participants (Vesselinov and Grego, 2012). These results are in line with the findings of a meta-analysis reviewing 44 MALL journal articles, which found that around $70 \%$ of students in the experimental groups using mobile devices outperform their counterparts in control groups without such devices. Furthermore, analyses revealed that adults and school children experienced similar beneficial effects from MALL, learning-oriented software and general-purpose software had similar positive effects and midterm interventions (1-6 months) produced the best effects in MALL (Lee et al., 2014). The current empirical results indicate that mobile devices have an overwhelmingly positive effect on language acquisition and it is reasonable to implement them in teaching and learning practice. The long-term implementation of mobile devices in learning environment is mainly due to successful pilot projects (Burston, 2014), and for this reason it is highly recommended to design and conduct MALL pilot projects and to decide on the adaptation of MALL, based on findings (evidence-based decision making).

To tap the full potential of mobile devices, it is advisable to combine learning with games and game elements. The most well-known mobile language learning applications (Duolingo, busuu) include this idea as well and to motivate and encourage their users they offer app-based elements such as collecting points, winning awards or badges and passing levels. However, the approach of gamification tries a faster and more intensive experience of learning and using game techniques to make activities more engaging and fun (Kapp, 2012). It is applicable almost everywhere and when applied correctly, results in the desired learning outcomes. Analyzing 68 research studies about games for educational purposes including mathematic games, science, logic and linguistic games, it turned out that games are more interesting than conventional lesson instructions (Randel et al., 1992). On examining business games in management courses, results indicated that the game-based approach produced significant knowledge-level increases and therefore is superior to the conventional 
case approach (Wolfe, 1997). An excessive technical report on the effectiveness of instructional games indicates that the empirical research on the effectiveness of educational games is fragmented and there is no evidence that games are the preferred instructional method in all situations, but they can still provide effective learning (Hays, 2005).

Language learning has always been essential for our students at the Budapest Business School as they need to take at least two language exams for their degree. Therefore, we have always sought after new methods and tools to improve the quality of our language courses. In 2011 we realized that the popularity of smartphones has increased among our students, so we conducted a survey. According to this survey $(N=81)$, one in every three students learning German as a second language at our institution owned a smartphone. In the survey conducted two years later $(N=70)$ we found that almost half of our students have a smartphone. Building on the increasing penetration of smartphones, we designed in 2013 a pilot project on mobile language learning. Participants $(N=59)$ were enrolled for the project on a voluntary basis (Kétyi, 2013). Since not all students of our school owned a smartphone, we looked for a hybrid language learning application that could be used both on computer and mobile devices. The application we used in the project was busuu and the feedback of the participants was overwhelmingly positive, so one year later we conducted an effectiveness study with almost 100 learners $(N=94)$ of four languages $(\mathrm{Ger}-$ man, English, Spanish and Italian). Despite the sporadic and brief use of the app, busuu could contribute remarkably to the learning progression of the students (Bárcena et al., 2015; Kétyi, 2015). To ensure more application usage time, in 2015 we tried to combine learning with gaming (gamification) and tested an exclusively text-based game $(N=18)$. The chosen game was Lifeline, a real-time interactive sci-fi story, where the user can help the unknown astronaut with short messages to survive. Below we provide an overview of our research results, whilst an overlook of all researches between 2011 and 2015 can be found in the appendix (Table 5).

\section{Method}

\subsection{Research Design - Sample Size and Tools}

\subsubsection{Pilot Project (2013)}

The participants of the project were students of the Budapest Business School, Hungary's biggest college ( $N=59, M=21.03$ years), who learned German as a second language. For the purposes of the project a mobile language learning tool had to be used. Because of its easy registration process, the clear and functional design, and a very active and helpful community, busuu was chosen for the project. A special advantage of busuu was that it provided tasks and materials which are available via PC and mobile devices. The busuu mobile application can be used on both Android and iOS devices. The voluntary pilot project started in March and ended in May, 2013. During the project, participants had to complete a lesson of their own choice every week. In May the participants reported on their opinions and experience with busuu. We used an ICT and a mobile assisted language learning (MALL) questionnaire. 


\subsubsection{Busuu Project (2014)}

The participants of the study were studying four different foreign languages (German, English, Spanish, Italian) and all of them were native speakers of Hungarian ( $N=94, M=20.80)$. The study lasted for eight weeks and was conducted between March and May, 2014. The use of the busuu language learning tool was an addition to their language lessons, which generally took place over 90 minutes twice a week.

The main evaluation tool was a language test for all four languages. In addition to the language tests, we also performed a short motivation questionnaire. The language test and the motivation questionnaire were completed during a pre-measurement stage in the first week of March, 2014 and during post-measurement at the end of May, 2014. In May, the experimental group also had to fill out a short questionnaire about the busuu app.

We divided the participants into an experimental group and a control group. We asked the students whether they wanted to use busuu immediately in the spring semester or two months later in the summer. Those who chose the immediate access became the members of the experimental group and the others became the members of the control group. The former was composed of 51 students, while the latter had 43 students. One third of the students were male $(32.3 \%)$, and two thirds $(67.7 \%)$ female. This ratio is typical for the whole college, so none of the genders were over- or underrepresented.

\subsubsection{Lifeline Project (2015)}

In our latest, Lifeline project, participants were students who learned German as a second language $(N=18, M=20.94)$. Two weeks after the installation we inquired information in a post questionnaire concerning opinions and experiences with Lifeline. 


\section{Discussion}

\subsection{Pilot Project (2013)}

\subsubsection{The Main Findings of the ICT Questionnaire}

As the results indicate, our students are technically well equipped (Figure 1).

Figure 1. The main findings of the ICT questionnaire.

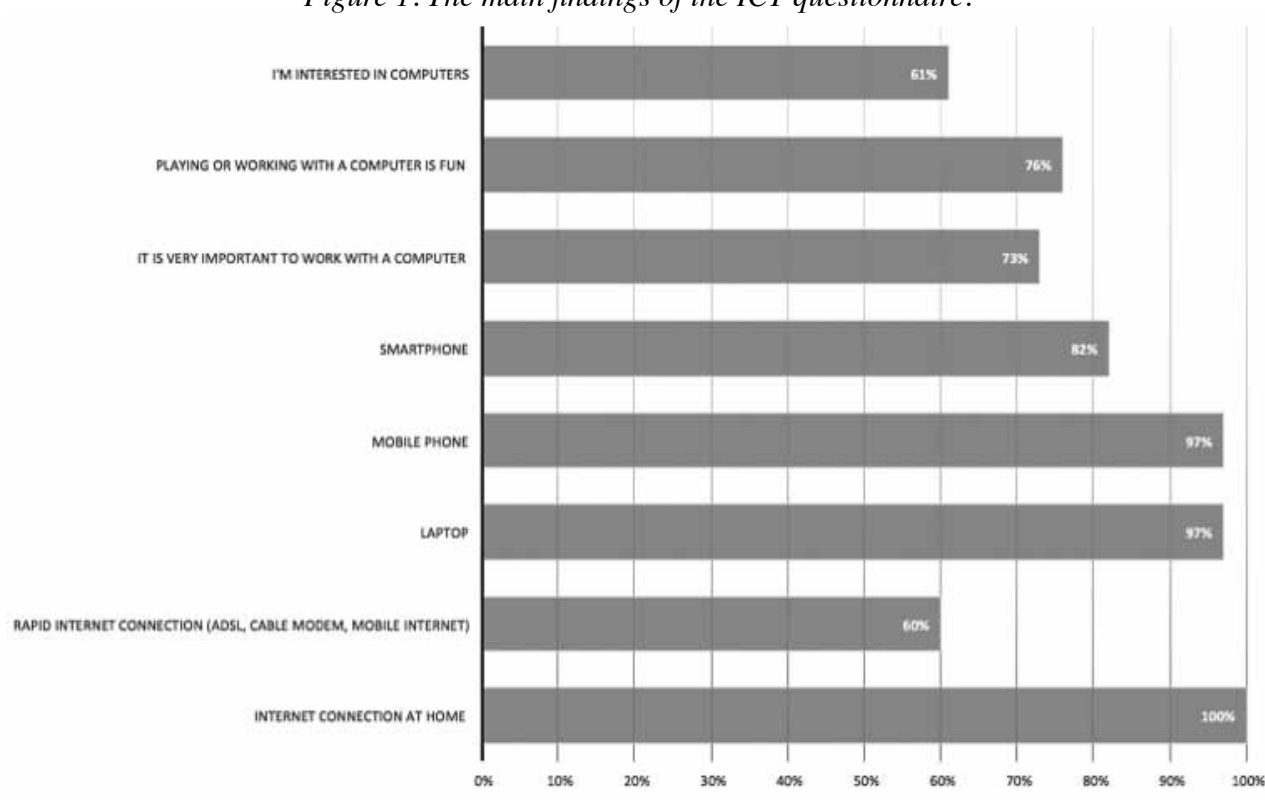

Every student has an internet connection at home and the majority $(60 \%)$ have rapid internet connection (ADSL, cable modem, mobile internet). $97 \%$ of the students use a laptop instead of a desktop computer. In contrast, our institution almost exclusively owns desktop computers instead of laptops. $97 \%$ of our students own a mobile device and $82 \%$ of these devices are smartphones.

For the majority of the students it is very important to work with a computer $(73 \%)$ and playing or working with a computer is really fun for them (76\%). Nevertheless, the majority of students have a pragmatic approach to technology; they are not using computers because they are very interested in them (61\%), but because they see their advantages.

\subsubsection{The Main Findings of the Mobile Assisted Language Learning (MALL) Questionnaire}

Before the project started, only two students had used a language learning system like busuu. Apart from the feedback of one participant, all other reactions on the first impressions were positive: "Funny, happy surface", "Just like a game or Facebook". The students participating in the project liked busuu very much, $79 \%$ rated it good or very good, although 
the majority (64\%) thought that acquiring a foreign language solely through busuu is not possible, yet they nonetheless saw it as a helpful tool in language learning. $92 \%$ of students would not pay after a 7-day-trial-period for premium membership. Interestingly, there were only two students who paid for an internet-based service (Figure 2).

Figure 2. The main findings of the MALL questionnaire.

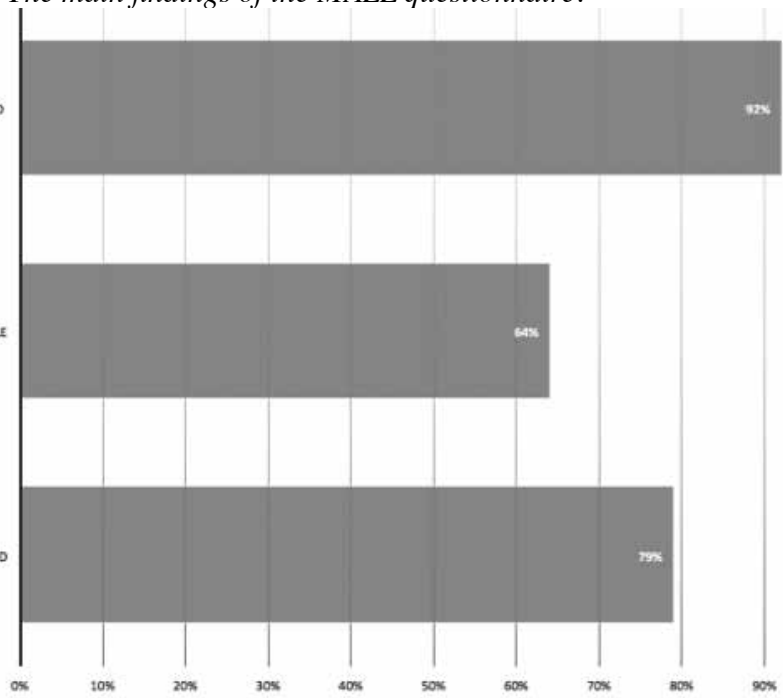

Almost all of the students mentioned vocabulary as the real strength of busuu. Due to a lack of the Hungarian language, the typical language setting of students was German-English (all of our students speak English) and in their comments many students added learning a lot of English words and idioms. Some of the students said that busuu was helpful not just for learning new stuff, but also for reviewing and practice. According to the students' feedback, the strengths clearly outweighed the weaknesses (Table 1).

Table 1. Strengths and weaknesses of the busuu language learning app.

\begin{tabular}{ll}
\hline Strengths & Weaknesses \\
\hline Playful and easy language learning & Fee for premium membership too high \\
\hline Provided information was not overwhelming & I miss my native language (Hungarian) \\
\hline Audio helped acquire the pronunciation & Lack of challenging tasks \\
\hline Vocabulary supported many common situations & busuu is boring after a while \\
\hline A wide variety of topics & \\
\hline Interactive online communication with other users & \\
\hline Immediate feedback & \\
\hline $\begin{array}{l}\text { Writing tasks were quickly corrected by other } \\
\text { busuu users }\end{array}$
\end{tabular}


The mentioned strengths were that language learning was playful and easy, the information provided was not overwhelming, the audio helped acquire the pronunciation, and the vocabulary supported many common situations and a vast variety of topics. Students also liked the interactive online communication with other users, the immediate feedback, and the idea that their writing tasks were corrected very quickly by other busuu users.

Most students did not add any weakness, but if they did so, they found the fee for premium membership too high. Additionally, some of them missed their native language (Hungarian) equivalents from the bilingual glossaries and had imagined more challenging tasks. Some of the students found busuu boring after a while.

Students also articulated their opinion about effective language learning methods. Despite the fact that the mobile language learning application busuu was very well received by most of the participants, they still needed, according to the feedback, real (mostly oral) communication with real persons; so language was still something lively and non-artificial. The majority of students thought that the most effective way to learn a foreign language was learning it abroad. For many students oral skills were essential (e.g. communicating with native speakers, learning through conversations, dialogues). Many of them also favored private lessons. Some of the students were aware of the importance of every-day-practice and motivation, and there were still many students who believed that the "conservative learning method" with books and exercises was the key to success ("Everyone should learn the basics first").

\subsection{The Busuu Project (2014)}

The busuu project has been our biggest MALL project to date and the only one where we also measured the language skills of the language learners.

\subsubsection{Effectiveness}

At the pre-test (placement test), the experimental group (53.7\%) performed better than the control group (47.5\%), but the difference was not statistically significant. During the research, according to the language test results, the experimental group increased their performance $(+2.2 \%)$ while the control group's performance decreased $(-3.1 \%)$, and the difference upon post-measurement became statistically significant $(\mathrm{p}=.013)$.

Table 2. Language test results of the control and experimental groups.

\begin{tabular}{|c|c|c|c|c|c|}
\hline & Group & $\mathbf{N}$ & Mean (\%) & Std. Dev. & Std. Error \\
\hline Pre-Test Result & Control & 43 & 47.54 & 16.41 & 2.50 \\
\hline & Experimental & 51 & 53.77 & 21.12 & 2.95 \\
\hline Post-Test Result & Control & 43 & 44.44 & 17.07 & 2.88 \\
\hline & Experimental & 51 & $55.91 * *$ & 21.91 & 3.26 \\
\hline$* * p<0.01 / * \mathrm{p}<0.05$
\end{tabular}




\subsubsection{Factors of Effectiveness (Gender, Study Time, Motivation)}

Analyzing the gender results, we found significant differences $(p=.032)$ in the progress of the experimental group where the female members performed better $(54.5 \%)$ than the male members $(44.2 \%)$. The performance of the male members of the experimental group decreased $(-4 \%)$, yet increased in the case of the female members $(+2.2 \%)$. Effectiveness according to initial level of language ability was not decisive, because at the pre measurement there were no significant differences between the control and experimental groups.

According to the answers to the post-busuu survey provided by the experimental group, the average study frequency was once per week and the average study length was between 10 and 15 minutes. For the entire research this entails only 120 minutes, 2 hours on average, which is a very low value. This low value cannot explain the significant difference between the two groups.

We asked the students to fill out a motivation questionnaire before and after the research. The questionnaire included 20 questions related to five major groups: the received benefits of language learning (1), individual impressions about language learning (2), the questions of getting feedback on language learning performance (3), some external factors of language learning motivation (4) and the willingness of spending time on language learning (5). The experimental group had higher values at the pre- and the post-measurement as well and we found that three of the five subcategories were statistically significant (Table 3).

Table 3. Motivation values of the control and experimental groups.

\begin{tabular}{|c|c|c|c|c|c|}
\hline & Group & $\mathrm{N}$ & Mean (\%) & Std. Dev. & Std. Error \\
\hline \multirow{2}{*}{ Pre-Motivation Value (Benefits) (1) } & Control & 43 & 8.98 & .91 & .13 \\
\cline { 2 - 6 } & Experimental & 51 & 9.15 & .86 & .12 \\
\hline \multirow{2}{*}{ Pre-Motivation Value (Impressions) (2) } & Control & 43 & 7.95 & 1.09 & .16 \\
\cline { 2 - 6 } & Experimental & 51 & $8.56^{* *}$ & 1.15 & .16 \\
\hline Pre-Motivation Value (Feedback) (3) & Control & 43 & 8.86 & 1.16 & .17 \\
\cline { 2 - 6 } & Experimental & 51 & $9.34^{*}$ & .74 & .10 \\
\hline \multirow{2}{*}{ Pre-Motivation Value (External) (4) } & Control & 43 & 7.12 & 1.56 & .23 \\
\cline { 2 - 6 } & Experimental & 51 & 7.42 & 1.60 & .22 \\
\hline Pre-Motivation Value (Time) (5) & Control & 43 & 8.30 & 2.08 & .31 \\
\cline { 2 - 6 } & Experimental & 51 & $9.33^{* *}$ & 1.08 & .15 \\
\hline Post-Motivation Value (Benefits) (1) & Control & 30 & 8.60 & 1.22 & .22 \\
\cline { 2 - 6 } & Experimental & 34 & $9.18^{*}$ & .77 & .13 \\
\hline Post-Motivation Value (Impressions) (2) & Control & 30 & 7.90 & 1.12 & .20 \\
\cline { 2 - 6 } & Experimental & 34 & $8.51^{*}$ & 1.20 & .20 \\
\hline Post-Motivation Value (Feedback) (3) & Control & 30 & 8.64 & 1.39 & .25 \\
\cline { 2 - 6 } & Experimental & 34 & 9.07 & 1.06 & .18 \\
\hline
\end{tabular}




\begin{tabular}{|c|c|c|c|c|c|}
\hline & Group & $\mathrm{N}$ & Mean (\%) & Std. Dev. & Std. Error \\
\hline \multirow{2}{*}{ Post-Motivation Value (External) (4) } & Control & 30 & 7.23 & 1.42 & .25 \\
\cline { 2 - 6 } & Experimental & 34 & 7.48 & 1.47 & .25 \\
\hline \multirow{2}{*}{ Post-Motivation Value (Time) (5) } & Control & 30 & 7.93 & 2.19 & .40 \\
\cline { 2 - 6 } & Experimental & 34 & $9.20^{* *}$ & 1.29 & .22 \\
\hline
\end{tabular}

$* * \mathrm{p}<0.01 / * \mathrm{p}<0.05$

We found significant differences in favor of the experimental group at both measurements in the 'individual impressions about language learning' and 'willingness to spend more time on language learning' groups. 'Getting feedback' had significant higher value at the pre measurement, but at the post measurement it disappeared and instead the 'individual benefits of language learning' had significantly higher values in the case of the experimental group.

Despite the statistically significant higher values of the experimental group, as far as the motivation scores were concerned, did not find any correlation between the test results and motivation.

\subsubsection{User Satisfaction (Feedbacks, Strengths and Weaknesses)}

The experimental group was asked to fill out a short questionnaire in the first few days after installing the busuu app. Again, the questionnaire was not mandatory, which is why we received only 19 responses from the experimental group. According to the results busuu was still a new and unknown app, and only one student had used the app before.

For the overwhelming majority of the users (58.4\%) it was easy to sign up and download the app, $26.3 \%$ found it average and for only one student thought it was difficult. The initial impressions of the busuu app were exclusively positive, $63.2 \%$ found the app OK, $31.6 \%$ good and $5.3 \%$ very good. Only one student experienced difficulties in starting the process, and the rest did good $(42.11 \%)$ or very good $(26.32 \%)$.

The function of the busuu app was smooth and stable. Half of the respondents $(52.6 \%)$ found that the app worked well and smoothly on their devices, $36.8 \%$ found it average, and $5.3 \%$ considered it worked badly or very badly. The lesson download speed was fast for $57.9 \%$, average for $36.8 \%$ and only one student thought it was too slow. Android was the most popular platform for our students followed by iOS and Blackberry and Samsung was the most popular smartphone although not everyone shared a specific phone type. The students used the app almost exclusively via their smartphone and only one of them used a tablet.

After a two-month premium access the experimental group had to complete a questionnaire about their experiences using busuu. According to the responses, vocabulary and writing were the skills where busuu helped the most (Figure 3). It is interesting that despite the feature to chat with native speakers, almost one third of the students didn't find busuu helpful in this regards. Another surprise was the good values for grammar, since many students indicated in the text-based feedback that the lack of grammar was one of busuu's weaknesses. The values in the chart below are inconsistent with that opinion. 
Figure 3. Contribution of busuu.

\section{How much did busuu help you with}

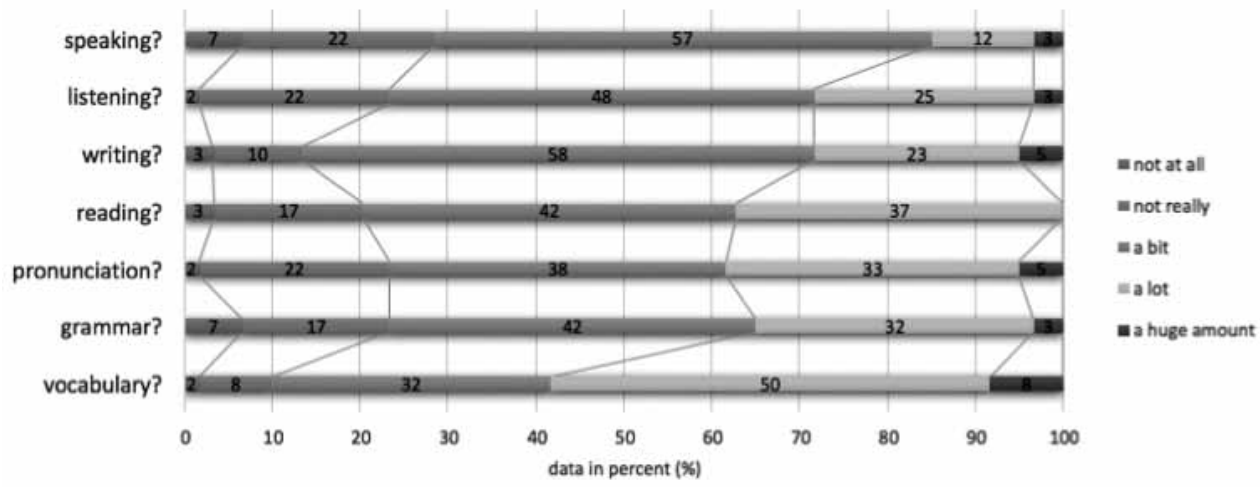

Half of the students gave text-based feedback on the strengths and weaknesses of busuu. The most frequently mentioned strengths were vocabulary acquisition ( 6 times), followed by the chat program and communication with other users (3), easy use (2), corrected written tasks by advanced users (2), online availability (2) and flexible use (2).

The most frequently mentioned weakness of busuu was the lack of grammar and few possibilities to improve the grammar skills (6) as well as a lack of reading comprehension tasks (3). Two students also lacked the support of their native language (Hungarian). Some students had technical issues, for example the app crashed often or the sync failed between laptop and smartphone. One student lacked the complexity of required language skills: "It doesn't need complex skills, you only need to know the words to reconstruct sentences. Tests and reviews should be more complex."

Furthermore, according to our post survey data, we found that:

- Language learning apps like busuu are still unknown among the majority of students. Only few students had used a similar program before busuu, five of them used Duolingo and one student used Livemocha. Two of them said the other app was better than busuu, one said that only the grammar part was better. Two of them think that busuu is a better app and one student can't decide either against or in favor of busuu.

- Busuu is a useful learning application. A little more than half of the students (55 $\%)$ learned a bit with busuu, one fifth $(20 \%)$ even a lot, yet a quarter of them not much $(20 \%)$ or nothing $(5 \%)$.

- Busuu is fun. Only $18 \%$ did not enjoy the time spent using the busuu app, half of the students had a bit of fun, almost $30 \%$ of them a lot and $3 \%$ even a huge amount.

- The overwhelming majority of the students (73.3\%) think that busuu can help, but is not the ultimate tool for language learning.

- Busuu could not achieve a regular use. The number of regular users (3-6 times a week) was below $10 \%$. Half of the students used the app less than once a week and $40 \%$ only once or twice. These results are a little bit surprising and disappointing. 
- Occasional short chunks of time are spent on learning. Slightly more than half of the students spent 10 to 20 minutes on busuu. Every fifth student used the app for less than 5 minutes and only every tenth student was a heavy user.

- After school is busuu time. The most common periods of using the app was in afternoon (after school lessons), commuting (to the school and from the school) and at night. It is a strength of the app that it can be used without an internet connection, which is typical when commuting for our students.

- The willingness to pay for busuu after a trial period of 7 days is very low. Three students said they would definitely pay for busuu after a trial period and three would consider it. This doesn't such much about the app itself as it is more likely a general attitude towards paying for an internet service, since two of the $60 \mathrm{stu}-$ dents were paying for services on the internet.

\subsection{Lifeline Project (2015)}

Every participant of our latest project had a smartphone, $70 \%$ of them an Android phone. One student had a Blackberry and could not use the app Lifeline, since it was only available for Android and iOS. The time of smartphone usage had increased, the majority of the students used their devices more than four hours per day. The main feature was still communication and social networking, and these features were mentioned by all students. The majority of the students did not use a great deal of applications, the average number of installed apps was 25 , which is a slight increase compared to the previous projects. The maximum number of installed applications was 70. The most popular apps used by students were for communication and social networking, such as Messenger, Facebook, WhatsApp, Instagram, Pinterest, Snapchat and Threema. Other popular apps included Spotify (music app), Dubsmash (video app) and Lifeline (game). Language learning apps were emerging, especially Doulingo, yet Quizlet was well known as well. Paid apps were still not so popular amongst students, yet this time there were a greater number of students who were willing to pay for apps such as Runtastic PRO (sport/fitness app), Deezer (music app), Threema (communication). The reason they paid for an app was mainly to access more services.

As for Lifeline, the strengths clearly outweighed weaknesses (Table 4). The mentioned strengths of Lifeline were interactivity ("the interaction", "the influence of the story", "the user reactions triggered by the permanent communication", "real time feedbacks", "the diversity of feedbacks, there are a lot of choices and no good and bad answers"), the good story ("the exciting story", "there is always a twist in the plot", "a slight addiction to the story of the astronaut Taylor", "the understandable story") and a different way of learning ("interesting way of learning", "a kind of flow experience", "the focused reading comprehension", "learning by reading an exciting story". One student also mentioned that "the grammatical constructions in the story are useful". If the students did include any weaknesses, they mentioned the intensity of feedbacks ("information overload", "too quick answers", "because of the quick feedbacks I have to react immediately"), lack of alternatives ("I can not choose an alternative option") and progress in the story ("if Taylor, the astronaut dies, I have to repeat the story", "Taylor, the astronaut sleeps too often and I can not go further in the story"). One student missed the native language ("I can not play it in Hungarian (-)") and one did not like the genre ("actually, I do not like sci-fi stories"). 
Table 4. Strengths and weaknesses of Lifeline.

\begin{tabular}{|l|l|}
\hline Strengths & Weaknesses \\
\hline Interactivity & Intensity of feedbacks \\
\hline Good story & Lack of alternatives in the storyline \\
\hline Different way of learning & Progress in the story \\
\hline
\end{tabular}

The overwhelming majority of students thought that Lifeline can help them to learn a language, especially in learning new phrases and words and they enjoyed the game (Figure 4). Some specific examples of how and what they learned during the game included the following: "I read a lot", "To find new words I used a dictionary frequently", "I learned phrases for daily communication", "I learned synonyms and word order", "I liked the very realistic style of dialogs and learned a lot from it", "I learned a lot of new words", "I think now I can better understand conversations", "I learned some grammatical constructions", "the whole story was very motivating for me", "if you have fun, you learn more easily".

Curiosity was a great motivator for students, as they played the game daily, some of them several times per day. The average time spent on Lifeline was more than an hour (66 minutes) and this is much higher than the average time spent with the language learning app busuu from our previous project. So Lifeline achieved more regular and longer use than busuu.

Figure 4. Contribution of Lifeline.

\section{How much did you learn with Lifeline?}

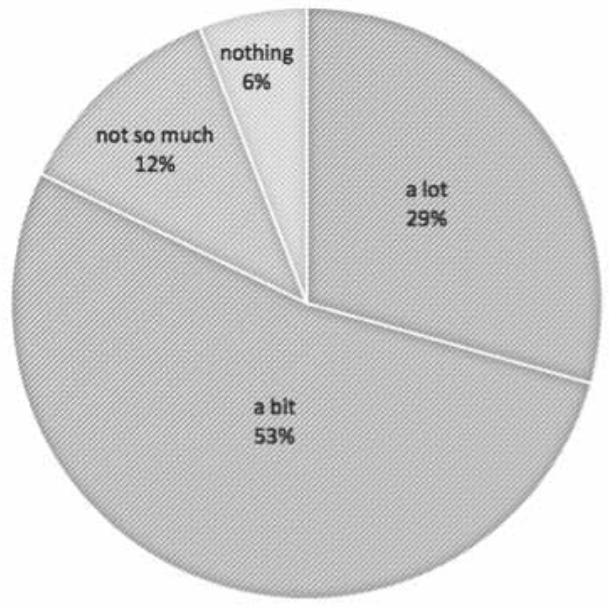

\section{Did you enjoy Lifeline?}

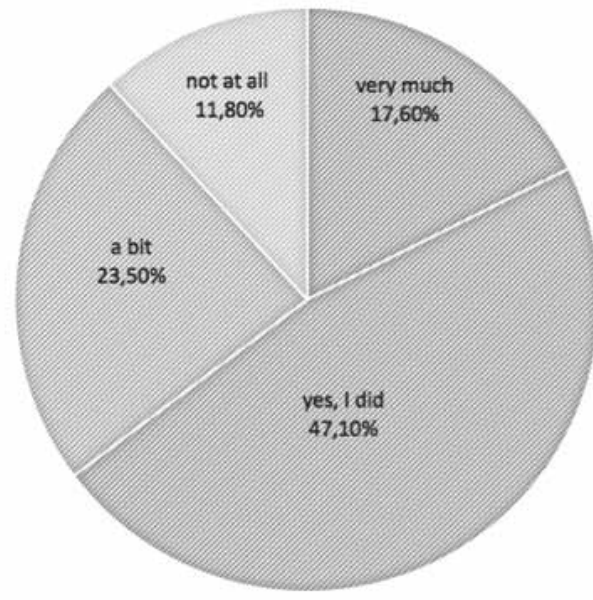

Another difference between Lifeline and busuu was noticeable in the use of the app during the day. While students used busuu mostly after school, at night and while traveling, the use of Lifeline became more diverse and ubiquitous. Students used it "at night", "while 
travelling to school", "on the road to and from school", "before and after breakfast", "in my resting times", "before sleeping", "in very different periods", "always a little bit, but mainly while travelling", "in the afternoon", "in my spare time", "at home to relax".

\section{Conclusion}

As the technical conditions for mobile language learning are given - smartphones are available for all students and everyone has an internet connection and a laptop at home - it is not a problem anymore to integrate MALL into the teaching practice. In this manner our students can gain valuable additional learning time outside school and can improve their language learning efficiency.

Despite the full penetration of smartphones, busuu and similar language learning applications are still new and unknown for students. The mobile language learning application chosen for our first two projects, busuu, was positively received by participants. However, at least for the time being, they had a serious limitation in large scale language teaching, because the 7-day-trial-period is far too short for an effective use of the app in practice.

According to the students' experience, the use of busuu is easy and simple, and its strengths clearly outweigh its weaknesses, yet unfortunately using the app did not become a regular habit, as the students spent very little time using it. Despite the sporadic and brief use of the app, busuu could contribute remarkably to the learning progression of the students, the experimental group increased their performance during the research and the difference at the post measurement was statistically significant $(\mathrm{p}<0.01)$. These findings are consistent with a related MALL research (Vesselinov and Grego, 2012). Analyzing the gender results, we found that female students performed significantly better at the post measurement than male students $(\mathrm{p}<0.05)$. We also found that overall, the experimental group was more motivated, the difference of the motivational values was significantly higher in three out of five sub-categories, yet we did not find any correlation between the test results and motivation values. Despite the good test results, students thought that busuu provides limited help with language skills and the vast majority wouldn't pay for the app after the trial period.

Although learning apps have become more popular recently they can still not reach the popularity and the regular use of applications for communication, social networking and games. That is why the concept of gamification, combining learning with games could be an option to be seriously considered for future MALL projects. In our latest MALL project using the interactive text-based game Lifeline, we found that the time spent with the application increased intensively along with the average study frequency.

\section{NeXT STEPS}

Since we did not measure the effectiveness of the game Lifeline with language tests, we cannot state that Lifeline is more effective than the language learning app busuu. However, the greater amount of positive feedback in the students' survey suggests that it could be more motivating. Therefore, we are planning to measure the effectiveness of Lifeline next 
semester with more measuring tools, such as a language test and motivation questionnaire. We hope that by the end of May, 2016 we will have clear evidence to prove the effectiveness of Lifeline in language learning.

\section{REFERENCES}

Abdous, M., Camarena, M. and Facer, B. (2009). "MALL technology: Use of academic podcasting in the foreign language classroom.", in $\operatorname{ReCALL}, 21.1$ : 76-95.

Bárcena, E. et al. (2015). "State of the art of language learning design using mobile technology: sample apps and some critical reflection." In Helm, F., Bradley, L., Guarda, M. and Thouësny, S. (eds.), Critical CALL - Proceedings of the 2015 EUROCALL Conference, Padova, Italy, Dublin: Research- publishing.net, 36-43.

Burston, J. (2014). "A Survey of MALL Curriculum Integration: What the Published Research Doesn't Tell.”, in CALICO Journal, 31, 3: 303-322.

Goodwin-Jones, R. (2011). "Emerging Technologies: Mobile Apps for Language Learning.", in Language Learning \& Technology, 15, 2: 2-11.

Hays, R. T. (2005): "The effectiveness of instructional games: A literature review and discussion.", available from: http://faculty.uoit.ca/kapralos/csci5530/Papers/hays_instructionalGames.pdf, accessed 24 February, 2016.

Kapp, K. M. (2012). The gamification of learning and instruction: game-based methods and strategies for training and education. United States of America: Pfiffer, A Wiley Imprint.

Kétyi, A. (2013). "Using Smart Phones in Language Learning - A Pilot Study to Turn CALL into MALL.", in Bradley, L. and Thouësny, S. (eds.), 20 Years of EUROCALL: Learning from the Past, Looking to the Future. Proceedings of the 2013 EUROCALL Conference, Évora, Portugal, Dublin/Voillans: Research-publishing.net, 129-134.

Kétyi, A. (2015). "Practical evaluation of a mobile language learning tool in higher education." In Helm, F., Bradley, L., Guarda, M. and Thouësny, S. (eds.), Critical CALL - Proceedings of the 2015 EUROCALL Conference, Padova, Italy, Dublin: Research-publishing.net, 306-311.

Kukulska-Hulme, A. (2009). "Will mobile learning change language learning?", in: ReCALL, 21, 2: $157-165$

Kukulska-Hulme, A. and Shield, L. (2008). "An overview of mobile assisted language learning: From content delivery to supported collaboration and interaction.", in $\operatorname{ReCALL}, 20,3: 271-289$.

Lee, Y.-S., Sung, Y.-T., Chang, K.-E., Liu, T.-C. and Chen, W.-C. (2014). "A Meta-Analysis of the Effects of Learning Languages with Mobile Devices.”, in: Y. Cao, T. Väljataga, J. K. T. Tang, H. Leung and M. Laanpere (eds.), New Horizons in Web Based Learning, Springer International Publishing. 106-113.

Palalas, A. and Olenewa, J. (2012): "Mobile-assisted language learning: Enhancing student learning with mobile phones at George Brown College.", available from: http://teachonline.ca/ pockets-innovation/mobile-assisted-language-learning, accessed 24 February, 2016.

Randel, J.M., Morris, B.A., Wetzel, C.D., Whitehill, B.V. (1992). "The effectiveness of games for educational purposes: a review of recent research.”, in Simulation \& Gaming, 23, 3: 261-276.

Stockwell, G. (2008). "Investigating learner preparedness for and usage patterns of mobile learning", in ReCALL, 20, 3: 253-270.

Stockwell, G. (2010). "Using mobile phones for vocabulary activities: Examining the effect of the platform.", in Language Learning \& Technology, 14, 2: 95-110. 
Vesselinov, R. and Grego, J. (2012): "Duolingo Effectiveness Study.", available from: http://static. duolingo.com/s3/DuolingoReport_Final.pdf, accessed 24 February, 2016.

Viberg, O. and Grönlund, Å. (2012): "Mobile Assisted Language Learning: A Literature Review.", available from: http://ceur-ws.org/Vol-955/papers/paper_8.pdf, accessed 24 February, 2016.

Waycott, J. and Kukulska-Hulme, A. (2003). "Students' experiences with PDAs for reading course materials.", in Personal and Ubiquitous Computing, 7, 1: 30-43.

Wolfe, J. (1997). "The effectiveness of business games in strategic management course work.", in Simulation \& Gaming, 28, 4: 360-376. 


\section{APPENDiX}

Table 5. An overlook of measuring tools and main research results between 2011 and 2015.

\begin{tabular}{|c|c|c|c|c|c|c|c|c|c|c|c|}
\hline 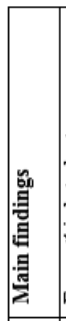 & 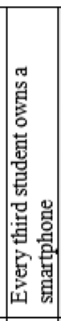 & 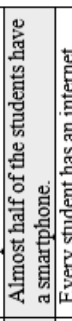 & 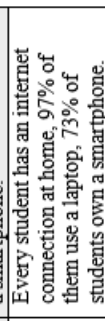 & 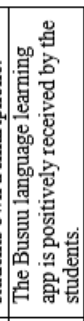 & 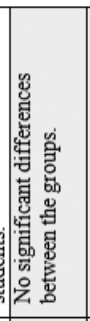 & 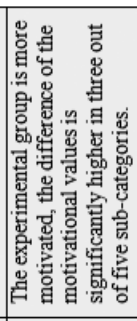 & 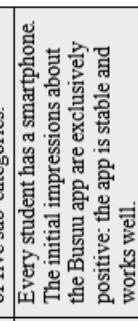 & 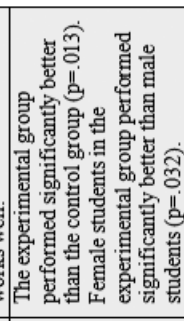 & 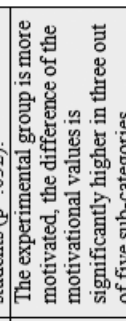 & 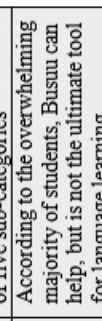 & 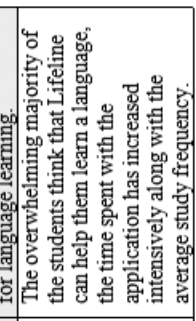 \\
\hline : & 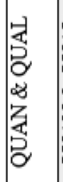 & 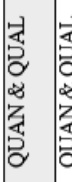 & 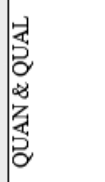 & 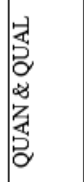 & 否 & 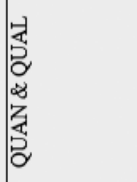 & 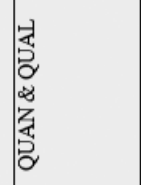 & 嫑 & 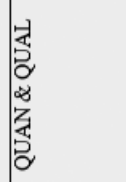 & 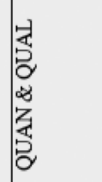 & 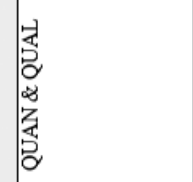 \\
\hline 贺 & & 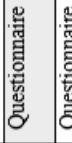 & 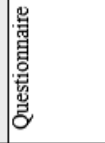 & 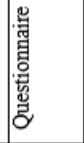 & 蒡 & 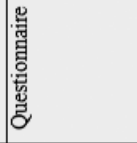 & 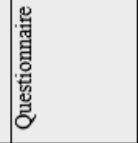 & 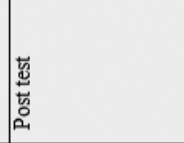 & 哯 & 题 & 昜 \\
\hline : & , & . & ' & . & 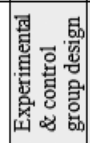 & 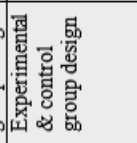 & 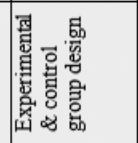 & 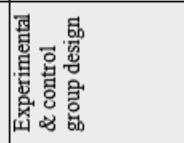 & 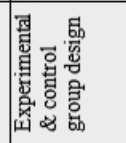 & 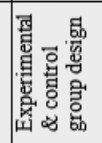 & \\
\hline 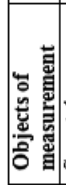 & 影 & 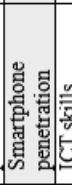 & 菷 & 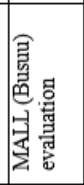 & 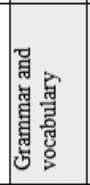 & 题 & 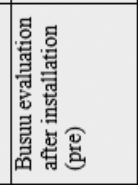 & 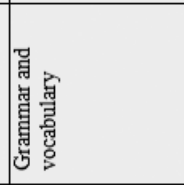 & 总 & 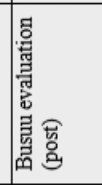 & 惫营 \\
\hline 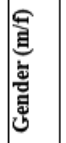 & ' & $\begin{array}{l}4 \\
4 \\
\vdots \\
0 \\
0\end{array}$ & 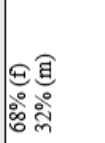 & 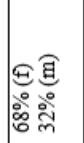 & 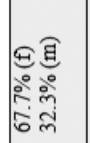 & 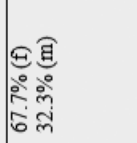 & 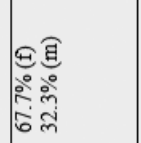 & 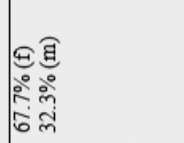 & 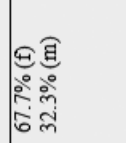 & 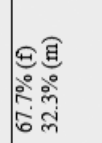 & 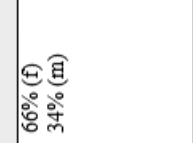 \\
\hline 路司 & & . & ô & $\begin{array}{l}\tilde{n} \\
\dot{\mathrm{n}} \\
\end{array}$ & 㐫 & 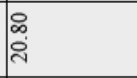 & 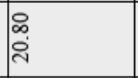 & ஷి & $\begin{array}{l}\infty \\
\infty \\
\stackrel{\sim}{*}\end{array}$ & 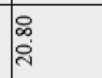 & ষ̀. \\
\hline 党 & $\vec{\infty}$ & 2 & in & in & 部 & 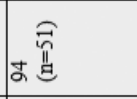 & $\underset{\Delta}{\stackrel{\pi}{\pi}}$ & 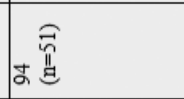 & 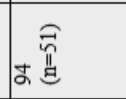 & 却 & $\cong$ \\
\hline 首 & 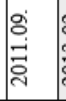 & 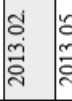 & ז̂ें & مُ & 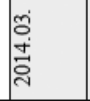 & 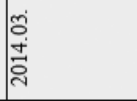 & 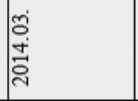 & 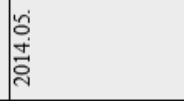 & 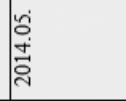 & 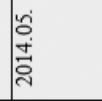 & 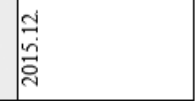 \\
\hline
\end{tabular}

$N$ : whole sample size; $n$ : experimental sample size; $f$ : female; $m$ : male; $Q U A N$ : quantitative; $Q U A L$ : qualitative 